Northwestern University School of Law Northwestern University School of Law Scholarly Commons

Faculty Working Papers

2008

\title{
A Single-License Approach to Regulating Insurance
}

Henry N. Butler

Northwestern University School of Law, h-butler@law.northwestern.edu

Larry E. Ribstein

University of Illinois College of Law

\section{Repository Citation}

Butler, Henry N. and Ribstein, Larry E., "A Single-License Approach to Regulating Insurance" (2008). Faculty Working Papers. Paper 154.

http://scholarlycommons.law.northwestern.edu/facultyworkingpapers/154 


\title{
A SINGLE-LICENSE APPROACH TO REGULATING INSURANCE
}

\author{
Henry N. Butler* \& Larry E. Ribstein** \\ Draft of May 19, 2008
}

\begin{abstract}
State regulation of insurance companies has been criticized for many years because of the burden imposed on insurers by having to comply with the laws of many jurisdictions. These higher costs are passed on to consumers. The problems with the current regulatory structure are prompting calls for increased federal regulation of insurance. However, all proposals to federalize insurance regulation create opportunities for abuse at the hands of the federal government and fail to utilize the benefits of a federal system. This article shows how many of the problems of the current system can be addressed without resorting to a large scale intrusion of federal regulators into insurance markets. The proposed solution calls for minimal federal intervention to provide for jurisdictional competition between states that would be allowed to charter insurers that could operate nationally with only the single license granted by the charter. This single-license approach addresses the most salient concerns of proponents of federal optional chartering. It also has the potential for triggering competition and innovation in insurance products and rates while preserving a meaningful role for state regulation.
\end{abstract}

* Executive Director, Searle Center on Law, Regulation, and Economic Growth, Northwestern University School of Law. The paper was prepared for and presented at the Searle Center's Research Symposium on "Insurance Markets and Regulation," which was held at Northwestern University School of Law on April 14 and 15, 2008. The views expressed are those of the authors and do not reflect an official position of the Searle Center. The authors are grateful for helpful comments by participates at the Searle Center Research Symposium and a faculty workshop at the Tilburg Law \& Economics Center (TILEC), as well as for the research assistance provided by Jonathan Hillel and Bernard Lam.

** Mildred van Voorhis Jones Chair in Law, University of Illinois College of Law. 


\section{THE CURRENT REGULATORY STRUCTURE 4}
A. Why Regulate InSURANCE?
B. The Structure of Insurance Regulation
C. ARGUMENTS FOR FEDERAL REGULATION

\section{A CRITIQUE OF FEDERAL REGULATORY REFORM PROPOSALS 8}
A. THE FALSE PROMISE OF FEDERAL REGULATION
B. THE TREASURY PLAN AND The NATIONAL INSURANCE ACT: Optional FEDERAL CHARTERING10
C. SMART ACt: Minimum FEDERAL STANDARdS AND PREEMPTION
D. Insurance Consumer Protection Act: Mandatory Federal Chartering ANd CREATION of FEDERAL INSURANCE REGULATION
E. Comprehensive Restructuring of FEderal Financial Services Regulation
F. SUMMARY

\section{THE SINGLE-LICENSE SOLUTION}

A. REMOVING BARRIERS TO ENTRY AND EXIT

B. TAX INCENTIVES FOR JURISDICTIONAL COMPETITION

C. MARKET-BASEd SOLVEnCY STANDARDS

D. Choice of Consumer Protection LAW

A. THE CASE FOR FEDERAL LAW

1. Race to the bottom

2. Excessive state regulation

B. OfFice OF NATIONAL INSURANCE 
State regulation of insurance companies has been criticized for many years. ${ }^{1}$ Many criticisms reflect the views of the insurance industry that inconsistent state regulations drive up costs because of the burden of compliance with multiple jurisdictions, limit product innovation and competition, and prevent companies from exiting jurisdictions that impose burdensome regulation. Under the current regulatory system, each state government is the monopoly insurance regulator within the state. Although the states exchange information through the National Association of Insurance Commissioners, state regulators' willingness and ability to experiment is constrained by the threat that the experiments might attract federal regulation. ${ }^{2}$ Thus, despite its appearance of being decentralized federalism, the current state-based regulatory system does not capture the benefits of jurisdictional competition that are found in other areas of the law, notably including corporate law. ${ }^{3}$

The problems with state regulation and concerns about the competitiveness of U.S. insurers in global financial markets have led to pressure for a greater federal role in insurance regulation. ${ }^{4}$ Several proposals to federalize insurance regulation have been advanced. ${ }^{5}$ The most seriously considered proposal calls for optional federal chartering (OFC) of multi-state insurers. ${ }^{6}$ Although OFC was recently endorsed by the U.S. Department of Treasury, ${ }^{7}$ the insurance industry is divided in its support of OFC. ${ }^{8}$ All proposals to federalize insurance regulation share the defect of the current system of failing to take advantage of jurisdictional competition to generate a more efficient regulatory structure.

This article shows how many of the problems of the current system can be addressed without resorting to a large scale intrusion of federal regulators into insurance

1 See Peter J. Wallison, Introduction, in OPTIONAL FEDERAL CHARTERING AND THE REGULATION OF INSURANCE COMPANIES (Peter J. Wallison, ed., 2000) (hereinafter Wallison).

2 See Scott E. Harrington, The History of Federal Involvement in Insurance Regulation, in Wallison, supra note 1, 27-37; Bert Ely, The Fate of the State Guaranty Funds after the Advent of Federal Insurance Chartering, in Wallison, supra note 1, 135, 138.

3 See Roberta Romano, THE GENIUS OF AMERICAN CORPORATE LAW (1993).

4 See Robert C. Eager, Creating Federal Insurance Regulation: A Zero-Based Approach, in Wallison, supra note $1,153,153$ (“... the growing sense that a federal platform for insurance is needed for competitive reasons in a national - indeed, international—marketplace.”).

${ }^{5}$ For a summary of current proposals to federalize insurance regulation, see Elizabeth F. Brown, The Fatal Flaw of Proposals to Federalize Insurance Regulation, available on SSRN. Paper Presented at Northwestern University School of Law's Searle Center Research Symposium on Insurance Markets and Regulation, April 14 and 15, 2008.

6 See Hal S. Scott, Optional Federal Chartering of Insurance: Design of a Regulatory Structure, Harvard Law School Public Law Research Paper No. 07-05, available at http://ssrn.com/abstract=985579. Paper Presented at Northwestern University School of Law's Searle Center Research Symposium on Insurance Markets and Regulation, April 14 and 15, 2008.

7 The Department of The Treasury, Blueprint For a Modernized Financial Regulatory Structure (March 2008).

8 Jeffrey H. Birnbaum, Insurers Are At Odds Over Paulson Plan: New Federal Overseer Favored Mainly by Large Companies, The WASHINGTON Post, Saturday, April 19, 2008; Page D01. 
markets. The proposed solution calls for minimal federal intervention to provide for jurisdictional competition between states that would be allowed to charter insurers that could operate nationally with only the single license granted by the charter. The singlelicense solution has the potential for triggering competition and innovation on insurance products and rates while preserving a role for meaningful state regulation.

Discussion proceeds as follows. Part I provides a brief introduction to the rationale for insurance and history of insurance regulation and the criticisms of the current regulatory structure that have led to calls for federal intervention.

Part II evaluates current proposals for federal involvement in insurance regulation. In general, it shows that the promise of short-term cost savings could lead to long-term inefficiency both in the static sense of misguided regulation and the dynamic sense of the opportunity costs of forgoing the advantages of a competitive regulatory system.

Part III proposes a jurisdictional competition approach to insurance regulation. Under the single-license proposal, states would be allowed to charter insurance companies that would be licensed to operate nationally. Our proposal is based on letting firms choose their state regulator, which would facilitate jurisdictional competition without either the impediment of a federal competitor or exposing insurers to multiple regulators. Insurers could choose their chartering state, subject to federal minimum standards based on a market test for solvency. They could also choose their preferred law to govern application and validity of their insurance policies, subject to limited state ability to override by legislation the application of the chartering state's law. The singlelicense approach would permit a dynamic process for experimentation and improvement of insurance regulation that would improve the international competitiveness of American insurers, while at the same time ensuring the financial soundness of insurers and preserving a limited state ability to protect consumers. The proposal calls for federal intervention only to the extent of ensuring that states allow nationwide operations with a single license, as well as allocation of taxing authority between the chartering state and the state of the insured.

Part IV considers the potential for a residual federal role in providing substantive regulation. The federal government might mitigate any remaining possibility of a race to the bottom under the single-license approach, as well as protecting insurers from the threat of multiple state regulations. However, any federal substantive regulation must be designed not to unduly undercut the benefits of viable state competition.

\section{THE CURRENT REGULATORY STRUCTURE}

An understanding of the history and underlying economics of insurance regulation is essential to considering the direction this regulation should take. This Part considers the rationale for regulation of insurance, what explains the current regulatory structure, and the problems with the current system. 


\section{A. WHY REGULATE INSURANCE?}

Insurance regulation has two broad and intertwined functions - protection of consumers from unfair insurance contracts, and ensuring the safety and soundness of the companies themselves. ${ }^{9}$

An important basis of consumer protection is the supposed information asymmetry between unsophisticated consumers and insurance companies. Insurance policies are classic adhesion-type contracts presented to consumers with little or no opportunity for bargaining over the terms. They are presented in arcane language that consumers that even many lawyers have difficulty understanding. It is accordingly difficulty or impossible for an individual consumer to meaningfully compare policies. This is complicated by the peculiarly contingent nature of insurance that seems to justify regulation. Consumers pay up front for the insurance company's performance - coverage against risk - that is contingent on the occurrence of an often distant and unlikely event. Consumers may be unable to evaluate at the time they buy the policy their coverage for the risk that eventually occurs. As a result, insurers have an incentive to overcharge for what turns out to be rather narrow coverage.

Safety-and-soundness regulation involves the temporal nature of insurance that triggers a concern that the insurance company will not be able to pay when it is called upon to do so. Insurers have an incentive to charge low prices to attract customers in the short run though this may increase the likelihood of default when the claims come due. Thus, while consumer protection oriented regulators are worried about rates being too high for the amount of coverage, safety-and-soundness regulators are concerned about rates being too low to ensure the company will pay for covered risks.

An additional challenge inherent in safety-and-soundness regulation concerns the link between this regulation and state guaranty funds that protect consumers by giving them a source of funds when insurers default. These funds create a moral hazard by potentially reducing the insurance industry's incentive to guard against default. Thus, as with federal deposit insurance, the existence of these state funds must be tied to state regulation of financial solvency.

Despite these problems for consumers, there are significant arguments against strict regulation. Many insurers sell their products in a vibrant competitive market. Even if many individual consumers do not have the time or expertise to track solvency or figure out policies, some do, and the size of the market justifies the entry of expert intermediaries. Moreover, insurers' emphasis on standard-form contracts and pricing makes price discrimination difficult. Accordingly, competition gives insurers an incentive to offer terms acceptable to the more sophisticated buyers. ${ }^{\mathbf{1 0}}$

Insurance, of course, is not the only financial service subject to regulation. Banking and securities are regulated as well. Insurance arguably differs from other

9 See generally Scott Harrington, Federal Chartering of Insurance Companies: Options and Alternative for Transforming Insurance Regulation, Policy Brief, Networks Financial Institute at Indiana State University, 2006-PB-02 (March 2006).

10 See Alan Schwartz \& Louis L. Wilde, Intervening in Markets on the Basis of Imperfect Information: A Legal and Economic Analysis, 127 U. PA. L. REV. 630 (1979). 
financial services on several dimensions. However, while we can define the current industry, there may be no economic reason for these borders to persist. For example, consumers can protect against risks by investing as well as by insuring. An important goal of insurance regulatory reform could be to set up an institutional framework that allows financial markets and products to evolve in response to market forces.

\section{B. THE STRUCTURE OF INSURANCE REGULATION}

The tensions in the current regulatory structure have been present for at least 140 years. When insurance companies expanded across state lines during the middle of the nineteenth century, they sought federal regulation to relieve them from the burdens of complying with regulations in multiple jurisdictions. ${ }^{11}$ U.S. Supreme Court's decision in Paul v. Virginia ${ }^{12}$ halted this effort in 1868 by holding that insurance contracts were not interstate commerce. However, the Supreme Court reversed course in 1944 in United States v. South-Eastern Underwriters Ass' $n^{13}$ where it held that insurance was interstate commerce and thus subject to federal antitrust regulation.

Though insurers favored a single federal regulator of insurance prior to Paul $v$. Virginia, they changed their tune after South-Eastern Underwriters presented them with the specter of federal antitrust regulation. Antitrust regulation threatens insurers' ability to enhance actuarial projections by cooperating through rating bureaus on the collection and dissemination of risk information. The insurance industry was anxious to remove the potential antitrust threat but did not have enough clout to get the federal regulation it wanted. They therefore joined with the state regulators through the National Association of Insurance Commissioners ("NAIC") to obtain passage of the McCarran-Ferguson Act of 1945.14 McCarran-Ferguson provided limited antitrust immunity for the insurance industry ${ }^{15}$ and established the states as the primary regulators of the insurance industry. ${ }^{16}$

McCarran-Ferguson instituted an era of regulation through dispersed state regulators, made somewhat palatable to insurers by state cooperation through the NAIC. However, several insurer failures in the late 1980s and early 1990s cast doubt on the adequacy of state guaranty funds and triggered renewed interest in federal regulation of insurance. Congress considered several proposals for federal chartering and regulation and the establishment of a federal guaranty fund. The NAIC successfully fended off this incursion onto their turf by encouraging state regulators to enact their own risk-based capital requirements for insurers, modeled after federal risk-based capital requirements

11 See Susan Randall, Insurance Regulation in the United States: Regulatory Federalism and the National Association of Insurance Commissioners, 26 FLA. ST. U. L. REV. 625 (1999).

1275 U.S. 169 (1868).

13322 U.S. 533 (1944).

14 Ch. 20, §1, 59. Stat. 33 (1945)(codified 15 U.S.C.S. §1011 (2004)).

15 For a discussion and policy analysis of McCarran-Ferguson, see Jonathan R. Macey and Geoffrey P. Miller, COSTLY POLICIES: STATE REGULATION AND ANTITRUST EXEMPTION IN INSURANCE MARKETS (1993).

16 See U.S.C.S. §§1011-1015 ("the business of insurance, and every person engaged therein, shall be subject to the laws of the several States which relate to the regulation and taxation of such business.”). 
for banks. However, the equilibrium may be shifting toward an increased emphasis on federal regulation.

The adoption of the Gramm-Leach-Bliley Act (GLB) is another significant development. GLB blurs traditional boundaries while at the same time maintaining existing formal distinctions in federal regulation of financial services. ${ }^{17}$ This uneasy situation increases the need for a system that erases artificial regulatory barriers.

\section{ARGUMENTS FOR FEDERAL REGULATION}

The whole idea of a state-based system for regulating insurance is now on the table. This makes particularly salient the long-unsettled question of whether insurance really should be regulated by the states. There are obvious scale economies in the sale of insurance, particularly including the cost advantages of a large risk pool and of selling standard-form policies. Insurance is, therefore, a national business, which seems to require national regulation.

The interstate nature of the insurance business casts doubt on the viability of state-based insurance regulation. Insurance companies operating in more than one state must comply with regulation in each state in which they sell insurance. As long as states have the power to bar firms from selling in their states, insurers must pay a regulatory tax in order to enter state markets. This gives states - particularly those like California with the most lucrative markets - the ability and incentive to impose inefficient regulation at the behest of local interest groups.

The problems of state-based regulation of insurance are manifest. First, the idea that each state should be regulating the prices insurers charge is highly questionable. State regulators have incentives to suppress rates below the level that the market would bear in order to satisfy consumer groups. Rate regulation is a particularly easy target for proponents of federal preemption. ${ }^{18}$

Second, insurers must get each state's regulatory approval of every policy they sell. The process itself is costly, as is insurers' inability to rely on uniform policies across the states in which they sell insurance. Among other things, states impose restrictions on insurers' underwriting and risk classification, which undercuts insurers' need to rely on national standards.

Third, states impose a variety of consumer-protection rules insurers must comply with regardless of where the companies are chartered or based. Unlike many types of contracts, insurance policies cannot effectively designate a single applicable law. Under the most commonly applied test, a state can disregard the contractually designated state if the designated law is "contrary to a fundamental policy of a state which has a materially

\footnotetext{
17 See Brown, supra note 5.
}

18 See Wallison, supra note 1 , at 10 ("The problem of nonessential regulation suggests that there could be significant compliance-cost reductions in a federal chartering and regulatory system, if the federal authority were to reduce nonessential regulation and nonuniform state conduct regulation not beneficial to the public.”). 
greater interest than the chosen state in the determination of the particular issue." ${ }^{19}$ States have considerable leeway in determining whether these conditions are met. ${ }^{\mathbf{2 0}}$

All of this could be ameliorated to some extent if insurers could exit states that impose excessive burdens. To be sure, as noted above, this is not a panacea for insurers since they would have to bear the penalty of losing sales in the state. But it would at least give insurers a stick they could hold over regulators, since consumers in the state would suffer from insurer exit. The problem is that states also bar the doors by imposing restrictions on insurer exit - and they may impose these barriers only after the insurer has entered the state. ${ }^{21}$

\section{A CRITIQUE OF FEDERAL REGULATORY REFORM PROPOSALS}

This Part discusses proposals for a federal fix of the current system of insurance regulation. Subpart A begins by sounding a general cautionary note about the advantages of a federal regulatory system. Although such a system may yield short-term gains over the current approach, it may well have long-term costs. The appropriate institutional design is far more important than the substantive content of the regulation. The remainder of this Part critiques the specific proposals that are on the table in light of these general considerations.

\section{A. THE FALSE PROMISE OF FEDERAL REGULATION}

The economic case for federal insurance regulation appears overpowering in light of the overreaching and inefficiency of the current state system. Calls for federal regulation are motivated by a desire to relieve the problems of duplication and overregulation that result from current allocation of regulation to the states. Indeed, the calls for reform may have the even more short-term motivation of a justified fear of being subject to aggressive regulators in states like Mississippi ${ }^{22}$ and Florida. ${ }^{23}$

However, in evaluating reform proposals it is easy to fall into the trap of overemphasizing short-term benefits from federal regulation that would remove the redundancies of the current state-based system. State regulation has important but perhaps less apparent long-term dynamic benefits of creating an institutional structure

\footnotetext{
19 See Restatement (Second) Conflict of Laws, §187(2) (1971).

20 See O'Hara \& Ribstein, THE LAW MARKET, Ch. 3 (forthcoming Oxford Univ. Press).

21 See Richard A. Epstein, Exit Rights and Insurance Regulation: From Federalism to Takings, 7 GEO. MASON L. REV. 293 (1999).

22 In the wake of Hurricane Katrina, Mississippi Attorney General Jim Hood sought to prevent State Farm Insurance Co. from "refusing to write new homeowners and commercial policies." In February, 2007, Hood announced that he would seek new legislation premised upon Florida's anti-cancellation measures, but going one step further. His plan would force firms currently offering auto insurance in Mississippi, and homeowners insurance in other states, to "write new policies" for homeowners insurance in Mississippi. This move was made in response to State Farm's announcement that "it has had enough of the 'untenable' legal and political climate in the state and is suspending writing new homeowners and commercial policies.” Associated Press, Miss. Official Seeks to Block State Farm, February 17, 2007, available at http://www.msnbc.msn.com/id/17187629/.

23 Tom Zucco, Allstate, Florida not backing off in insurance fight, ST. PETERSBURG TimES, Friday, April 18, 2008.
} 
that encourages experimentation and regulatory evolution in response to changes in exogenous and endogenous forces. In particular, a state-based system facilitates reversal of inevitable policy mistakes that can easily get locked in at the federal level. Consider, for example, the Sarbanes-Oxley Act, a hastily adopted law that brought increased federalization of previously state-dominated corporation law. ${ }^{24}$ Almost from the moment of its enactment, Sarbanes-Oxley has caused huge costs and problems for publicly traded firms. Yet there has still been no serious attempt to reform the legislation. Similarly, federal controls on interest rates outlasted their usefulness to the point that they bankrupted the entire savings and loan industry.

It is far from clear that a large federal role is necessary, even given the problems of state regulation. The states have shown that they can respond to the need to modernize regulation to enable firms to compete in a global market. ${ }^{25}$ The major problem with the current system of insurance regulation that needs to be fixed is that it turns what could be the big advantage for the United States in the global market place - the "genius" of our federal system - into a significant disadvantage, where domestic firms are crippled by multiple state regulation and foreign firms are deterred from entering. Also, instead of encouraging regulatory experimentation and competition, the NAIC stifles experimentation by setting standards and model rules.

The objective in reforming insurance regulation should be to fix the problems of state law without imposing the potential costs of federalizing insurance law. Understanding the need to preserve the dynamism of our federal system is far more important than trying to get the details of a regulatory fix exactly right for transitory current market conditions. Our policy proposals in Part III deal with the problems of state regulation without throwing the baby out with the bath water.

Large insurers may be skeptical of any approach that preserves state regulation. They may be convinced that they could more effectively control federal legislators and regulators than they can control legislators and regulators in fifty-one dispersed jurisdictions. And state-based consumer protection groups may just want to maintain the regulatory status quo. But federalization would introduce a new interest group dynamic that existing groups might find difficult to control. Many state-based consumer groups would be marginalized by a federal takeover of insurance regulation and replaced by new and more aggressive proponents of regulation. Under true jurisdictional competition, market forces could constrain and balance the often competing interests of insurers and consumer protectors. By contrast, under a federal regime, insurers would be forced to deal with a single legislature and perhaps a single regulatory agency. They would therefore be vulnerable to repeated threats of regulation and attempts to extract rents, ${ }^{26}$ with little ability to respond to the threat by exiting to another regime.

Reform proponents also tend to overestimate the likelihood that their favored proposal will work as intended. The task of determining appropriate or optimal standards

\footnotetext{
24 See Henry N. Butler \& Larry E. Ribstein, THE SARBANES-OXLEY DEBACLE (AEI 2006).

25 See Harrington, supra note 2 at 27-37 (noting that periodic crises have forced individual states and the NAIC to make gradual moves toward modernizing the regulatory system.).

26 See infra note 29 and accompanying text.
} 
under federal charters may appear simple and straightforward. After all, state regulators and the NAIC have been promulgating rules and regulations for a long time. Law professors and other experts may be so convinced they are right that they may find it difficult to believe that smart, well intentioned federal regulators could reach a different conclusion. However, reform of a complex system is immensely difficult to get right, even under the highly unrealistic assumption that current conditions will not change. If conditions do change, today's panacea will become tomorrow's problem. Meaningful reform requires establishing a system that will reach the right solutions today and tomorrow.

\section{B. THE TREASURY PLAN AND THE NATIONAL INSURANCE ACT: OPTIONAL FEDERAL CHARTERING}

The recently-unveiled Treasury Plan is similar to the National Insurance Act of 2007 and other legislative proposals that create a federal optional charter. ${ }^{27}$ For ease of exposition, the following discussion focuses on the Treasury Plan. The Treasury Plan would give multi-state insurance companies the option of obtaining a federal charter that would allow them to operate throughout the country without regard to state licensing and entry restrictions. The Treasury Plan would create a new Office of National Insurance (“ONI”) within the Treasury Department which would be headed by a Commissioner of National Insurance (“CNI”). The Treasury Plan would also establish an Office of Insurance Oversight (“OIO”) to (1) address international regulatory issues and (2) advise the Secretary on major domestic and international policy issues. Nationally chartered insurers would be exempt from state rate regulations.

OFC proposals are premised on the assumption that national regulators will provide more balanced and reasonable regulation than decentralized state regulators. Supporters of OFC argue that establishing an optional federal charter would not supplant state regulation or state premium taxation because OFC would allow insurers to choose between state and federal regulation. ${ }^{28}$

27 See Treasury Blueprint, supra note 7, at n. 110 ("Treasury recognizes that there are currently pending bills in both the House (H.R. 3200) and Senate (S. 40) entitled 'National Insurance Act of 2007' that would create an OFC and establish an ONI. It is not Treasury's intent at this time to opine on the details or merits of the pending legislation, but rather to set forth general guidelines as to the basics that it believes any ultimate legislation should contain in establishing an ONI and creating an OFC. That said, there are many positive attributes to these bills as they address many of the concepts raised in this report.”).

28 The OFC approach is often analogized to the dual banking regulatory structure. See Eager, supra note 4, at 154 ("Political reality dictates that a federal charter be optional and create a dual statefederal system. That is desirable because ... there is a real virtue to a system that fosters competition through choice. The dual banking system is a relevant model and on the whole demonstrates the competitive and regulatory vitality of a dual system.”); U.S. Treasury Department of Public Affairs, Fact Sheet: Treasury Releases Blueprint for a Stronger Regulatory Structure (March 2008) ("This structure is similar to the current dual-chartering system for banking.”). This analogy, however, should not convince anyone of the virtues of the optional charter. First, the virtues of the dual banking system are often overstated. See Henry N. Butler \& Jonathan R. Macey, The Myth of Competition in the Dual Banking System, 73 Cornell L. Rev. 677 (1988). Second, the presence of federal deposit insurance (which is available to both federal and state banks) dramatically distorts the type of market pressures that could be created in a vibrant market for insurance charters. For a discussion of one limited area where the dual banking system encouraged beneficial regulatory competition, see Henry N. Butler, The Competitive Equality Doctrine and the Demise of Intrastate Branching Restrictions, 55 TENN. L. REV. 703 (1988). 
The central problem with OFC is that it preserves only the mirage of competition. The NIA would let multi-state insurers either choose a single federal charter or continue to be subject to multiple state regulators just as they are now. Given the high costs of the state system, insurers would be highly likely to choose the federal charter. Thus, OFC is likely to evolve into an all-federal system. Moreover, insurers would gain little from this "choice," as federal politicians could engage in "rent extraction" by threatening regulation up to the difference between the regulatory costs under the federal regime and those under the state regime. ${ }^{29}$ Thus, insurers could lose the benefit of the gains associated with opting into federal regulation plus the transaction costs of resubmitting to licensing in each state.

One might wonder why this is so, since it would seem that insurers would recognize the risk of lock-in and rent extraction and just stay with the current system. But the drawback of that strategy lies in the very problem that is provoking calls for reform - the inadequacy of state funds. These funds provide a kind of product warranty, akin to federal deposit insurance, that state regulators will provide adequate protection. Thus, as Bert Ely has explained, "if government wants to be in the business, for whatever reason, of regulating financial institutions, then it has no choice but to provide a warranty for the service that business supposedly provides to the general public." 30 The problem is that as long as consumers demand a warranty, they are likely to insist on the stronger warranty the federal government can provide, particularly since the federal program may draw funds from already weak state funds. This is supported by the fact that non-federal deposit insurance almost completely disappeared in the wake of federal insurance. ${ }^{31}$

Even apart from the federal government's deeper pocket, OFC might dominate the current state-based system simply because of the defects of state law under the current regime. Because each state regulatory body currently has a monopoly over the regulation of insurance sold in that state, the states have had no incentive to compete to provide the most efficient regulation. A new federal competitor could start out by offering regulation that is superior to any state regulator. A few states might be able to quickly offer equal or superior regulation, but they would have to be significantly better in order to beat the deeper federal guaranty.

Thus, the fact that the market might ultimately accept federal chartering over state law does not necessarily mean that it is the superior solution. The problem is that, due to the federal government's deeper pocket and its exclusive opportunity to offer jurisdictional choice, federal and state chartering will not be competing on an even playing field. Even if insurers could choose a single state license or a federal license, this would still not be a good market test because the states would still have to compete with a deep-pocketed federal regulator. In any event, the need for a federal chartering option ultimately depends on the quality of state regulation under jurisdictional competition.

29 See Fred S. McChesney, Rent Extraction and Rent Creation in the Economic Theory of Regulation, 16 J. LEG. STUD. 101 (1987); R. Doernberg and Fred S. McChesney, Doing Good or Doing Well? Congress and the Tax Reform Act of 1986, 62 N.Y.U. L. REV. 891 (1987).

30 Bert Ely, The Fate of the State Guaranty Funds after the Advent of Federal Insurance Chartering, in Wallison, supra note 1, 135, 137-38.

31 Id. at 142. 
Under our proposal outlined in Part III, state competition would provide meaningful competition and assurances of solvency. This arguably eliminates the need to force the states into a one-sided competition with federal regulation and the solvency fund that bonds that regulation. After considering the single-license alternative, we will return to the optional chartering approach. ${ }^{32}$

In short, although OPM is being sold as a system that provides insurers with real choice, it does not actually deliver on this promise. OPM likely would lead to a system in which there is only one regulator, the federal government. If choice is good, as the proponents of OPM claim, ${ }^{33}$ policymakers should focus on designing a system that provides real choice. True choice may or may not involve the choice of a federal charter. What is clear is that the current OPM proposal does not involve true choice.

\section{SMART ACT: MINIMUM FEDERAL STANDARDS AND PREEMPTION}

The State Modernization and Regulatory Transparency (SMART) Act would effectively have the federal government establish minimum standards for many activities currently regulated by the states, including rates, policy forms, insurer and producer licensing, market conduct, surplus lines, reinsurance, solvency oversight, and receivership of insolvent insurers. It would create a National-State Insurance Coordination Partnership. This agency would have seven commissioners - a chairman nominated by the states and appointed by the President, three federal commissioners and three state commissioners. The SMART Partnership would have no direct regulatory authority, but a state's failure to follow NAIC model laws within three years of loss of regulatory authority.

Although SMART is characterized as a federal-state "partnership" and is designed to make it appear that it is not a federal takeover, federal law would preempt state rules that fail to meet the federal minimum standards within specified periods. This constraint on the evolution of state regulation effectively relegates SMART to a federal takeover of regulation. The basic problem is that the federal government cannot set minimum standards without ultimately coming to dominate the field. Where does the federal role end and the state role begin? SMART's risk of federalization is even clearer than the risk of potential federalization of corporation law in the earlier handiwork of one of SMART's main legislative proponents - Representative Michael Oxley of Sarbanes-Oxley fame. At least with the federal securities laws there is a boundary, albeit hazy, between disclosure and substantive regulation. But with SMART, the federal government would be regulating precisely in the same way as the states. The Supremacy Clause accordingly would not limit the federal reach. ${ }^{34}$

32 See infra subpart IV.C.

33 See Cantwell F. Muckenfuss III, Creating Federal Insurance Regulation: A Zero-Based Approach, in Wallison, supra note 1,161, 162 ("For proponents of the free market and the benefits of competition, the case for a federal regulatory alternative should be overwhelming and, in fact, for many years it has been overwhelming.").

${ }^{34}$ With respect to the application of the Supremacy Clause to federal securities regulation, see Larry E. Ribstein, Dabit, Preemption and Choice of Law, 2006 CATO SUPREME COURT REVIEW 141. 


\section{INSURANCE CONSUMER PROTECTION ACT: MANDATORY FEDERAL CHARTERING AND CREATION OF FEDERAL INSURANCE REGULATION}

The Insurance Consumer Protection Act of 2003 ("ICPA") would subject all multistate insurers to federal regulations. The newly-formed Insurance Regulatory Commission, a division of the U.S. Department of Commerce, would regulate all lines of insurance. All multistate insurers would be covered by a newly-formed National Insurance Guaranty Corporation. The ICPA would, among other functions, provide for consumer protection function, repeal McCarran-Ferguson, and eliminate the insurance industry's antitrust exemption. This proposal discards the apparent efficiency goal of the above proposals for a naked political compromise - more consumer protection in exchange for lower regulatory compliance costs.

\section{E. COMPREHENSIVE RESTRUCTURING OF FEDERAL FINANCIAL SERVICES REGULATION}

Professor Elizabeth Brown proposes a complete overhaul of federal financial services regulation. ${ }^{35}$ Professor Brown begins with a list of problems allegedly associated with all the proposals to federalize insurance including creating a race-to-thebottom between federal and state agencies competing for insurer chartering business; creating an uneven playing field between multistate and single state insurance companies; confusing consumers about which regulators are responsible for regulating particular companies; displacing state guaranty funds; and creating a massive new federal bureaucracy. ${ }^{36}$ Brown adds what she calls the "fatal flaw" of federal proposals - that they do "not make sense when the market for financial services is a continuum, not a series of discrete baskets." 37

Brown proposes to merge the Securities and Exchange Commission and the Commodities Futures Trading Commission into a super agency that would have regulatory authority over the insurance industry as well. Brown argues that this new federal agency would reflect the realities of the financial services marketplace in which it is often difficult to distinguish where one product definition ends and another begins. ${ }^{38}$

Although Brown correctly analyzes the fundamental changes in U.S. financial services markets that are merging previously discrete markets, her prescription for a consolidation of regulatory authority does not necessarily follow from this analysis. Brown's proposal would in effect put federal regulation on steroids by having one federal agency regulate everything. This would not only eliminate "horizontal" jurisdictional competition like the proposals discussed above, but also "vertical" competition among regulatory agencies. This proposal exhibits a great deal of confidence in a single set of

\footnotetext{
35 See Brown, supra note 5.

36 Id at 39.

37 Id at 43.

38 Id at 2 ("If the United States is going to federalize insurance, it should adopt a structure that recognizes the current realities of the financial services industry and not one that memorializes how the industry operated a decade ago.” ). Brown models her proposal after the United Kingdom's Financial
} Services Agency. 
federal regulators to get it right and keep it right. Unfortunately, there is no mechanism for correcting regulatory mistakes. ${ }^{39}$

\section{F. SUMMARY}

Both theoretical considerations and a review of the current legislative proposals for insurance reform suggest several institutional approaches to regulatory reform in this area. The first is the current state-based system, which has resulted in significant costs for insurers from opportunistic state regulators and courts and duplicative regulation. A second option would be federalizing the system, which could fix the short-term problems but prevent needed competition and experimentation. A third approach is a state-federal partnership involving minimum federal standards. However, putting the camel's nose of federal regulation under the tent likely will mean that the rest of the camel will soon follow - that is, full federalization of insurance regulation. Fourth, the federal government could become an optional chartering alternative. But, again, we have shown how this "partnership" could lead to a "sole proprietorship" of federal regulation. The next Part presents a proposal for real competitive federalism in insurance. Specifically, we suggest permitting insurers to choose a single state regulator that would govern their activities in all fifty states.

\section{THE SINGLE-LICENSE SOLUTION}

The states have had ample opportunities over the past half century to devise institutional structures that encourage the evolution of modern insurance regulation. Despite the current interest in federal legislation the state regulators seem content to make only marginal changes in the way they conduct their business. As a result, there is a widespread consensus that there are serious problems with the current state-based regulatory system. Yet, as discussed above, there are good reasons to be skeptical of the ability of federal regulators to get it right and keep it right. The tension reflected in these observations suggests the need for a policy response that triggers the development of meaningful jurisdictional competition while reducing the likelihood of immediate federal domination that is likely under OFC.

An alternative to the federal domination that is likely to occur under OFC or the other federalization of insurance proposals discussed above is to model federal insurance regulation after corporate chartering which takes advantage of the "genius" of jurisdictional competition. ${ }^{40}$ Under the regulatory federalism of the corporate chartering system, most internal governance is left to the chartering state, with a federal minimum standard that takes the form of disclosure regulation. An analogous proposal for insurance regulation would allow an insurer to be chartered in a primary state of their choice, and then would be licensed to sell in any state provided the insurer met minimum

39 International competition in financial services could serve to constrain Brown's federal regulatory behemoth (should the behemoth allow such competition), but the true cost of such centralization is that it would ruin any chance of taking advantage of the unique advantage that competitive federalism can provide to enhancing the competiveness of U.S. firms.

40 See Romano, supra note 3. 
federal standards. ${ }^{41}$ At one point, this single-license proposal had the support of the insurance industry. ${ }^{42}$

The single-license proposal is attractive because it captures both the static efficiency benefits that would be expected from moving to a single regulatory and the dynamic benefits of competitive regulatory federalism. However, unlike the proposals discussed in Part II, there would be no overall federal regulation of insurance. Insurers would get a single state charter under which they could do business everywhere. That state would both regulate solvency and provide the relevant guaranty fund. With regard to solvency regulation, the single-license system would not be much different from the current system regarding insurer solvency regulation because states currently rely primarily on the solvency regulation of the chartering (domiciliary) state. ${ }^{43}$ There would be no disjunction between state-chartered and federally-chartered firms, or the moral hazard presented when the regulator and the keeper of the fund differ.

The single-license system would not require creating new entities or massive new federal regulatory bodies. And because the federal government excluded itself from this regulatory area by McCarran-Ferguson, there is no federal regulatory apparatus to dismantle in order to institute effective state competition. The single-license approach would, however, require federal legislation. The states have had 60 years since McCarran-Ferguson to evolve toward jurisdictional competition and have instead embraced a state cartel under NAIC. The statute might, for example, provide for federal preemption except where states enforce choice of law clauses, thereby preserving state autonomy as long as the states do not use their authority to disrupt interstate commerce. Similarly, a federal law was necessary to establish chartering competition for captive insurers. ${ }^{44}$ Also, by analogy, the National Banking Act established a state choice of law regime for interest rates. ${ }^{45}$ However, we emphasize that the federal law we have in mind is a federal choice-of-law rule rather than substantive regulation of insurance.

Subpart A discusses the importance of opening the national market for singlelicense firms by removing state regulatory impediments to entry and exit. Subpart B discusses the important role that adjustments in the allocation of insurance tax revenues can play in spurring effective jurisdictional competition under the single-license approach. Subpart C discusses our proposal for market-based federal minimum insolvency standards. Subpart D presents the second qualification of constrained state mandatory consumer regulation.

41 See Scott Harrington, Federal Chartering of Insurance Companies: Options and Alternative for Transforming Insurance Regulation, Policy Brief, Networks Financial Institute at Indiana State University, 2006-PB-02 (March 2006).

42 Id.

43 See Wallison, supra note 1 , at 10.

44 See William J. Warfel, Insurance Regulatory Reform: An Evaluation of Options for Expanding the Role of the Federal Government (forthcoming CPCU eJournal 2007), available at http://ssrn.com/abstract=946457.

45 See 12 U.S.C. § 85. 


\section{A. REMOVING BARRIERS TO ENTRY AND EXIT}

The jurisdictional competition approach to insurance regulation could, in theory, evolve through reciprocal and multi-state agreements among states to recognize licenses granted in other states. This has not happened, and it not obvious that it would ever happen with the provincial nature of current state-based insurance regulation.

Accordingly, federal legislation mandating jurisdictional choice is necessary in order to fashion state regulation into a meaningful alternative to intrusive federal substantive regulation. Specifically, the federal statute should clearly authorize a state to charter insurance companies that can operate in all other states, subject only to nondiscriminatory solvency regulation that the non-chartering state imposes on insurers chartered in that state. This would enable consumers in every state to shop for insurance from companies regardless of where they are chartered based on price, quality and type of product.

In order for meaningful jurisdictional competition to occur as to any aspect of insurance regulation, insurers must not only be able to select any chartering or regulating state that is attractive to them, but also to exit states that change their regulation. The main qualification on exit is that states need to be able to protect against a drain on potential contributions to the state guaranty fund. Indeed, there are existing state associations, the National Conference of Insurance Guaranty Funds for P\&C insurers and the National Organization of Life and Health Insurance Guarantee Associations (NOLHGA), which protect against this risk. ${ }^{46}$ These institutions suggest that states can deal with this problem. The concern is that states might go further and, for example, require insurers to pay a large exit fee if they wanted to reincorporate in another state. Firms can protect themselves to some extent by refusing to enter states that impose such restrictions. The danger is that states will impose these restrictions for the first time after the insurer enters the state. ${ }^{47}$ To protect against this risk, any federal choice-of-law or chartering statute must include provisions designed to facilitate low-cost exit.

\section{B. TAX INCENTIVES FOR JURISDICTIONAL COMPETITION}

A robust market for insurance regulation requires that states have an incentive to compete to provide such regulation. This incentive can be provided by properly allocating state tax revenue from insurance sales. ${ }^{48}$ The reallocation of insurance tax revenues could play an important role in spurring the type of jurisdictional competition proposed in this paper. However, it is unlikely that the states will agree on their own to such a reallocation because many - perhaps most - states will be net losers under this

46 See Ely, supra note 30 at 139.

47 See Epstein, supra note 21.

48 The need for this incentive indicates a further flaw in optional federal chartering. Proposed OFC would not affect the current allocation of state tax revenues on the basis insured's state of residence. The states accordingly would have little incentive to modify their insurance regulation in response to competition from federal chartering. Supporters of OFC may have wanted to make their proposal more palatable by not making it look like a federal revenue grab. And, to be sure, allocating revenue from federal chartering to the federal government would have that effect. But the solution is to forego the federal regulator rather than adding one on a basis that would further weaken state competition. 
system. Accordingly, designing a federal jurisdictional choice statute requires considering the appropriate allocation of state tax revenues.

The most straightforward allocation would be for the insurance tax revenue to go to the chartering state of the insurance company that sells the policy. Because a substantial amount of revenue is at stake, it seems likely that several states would be willing to invest in creation of a regulatory environment that makes their state an attractive primary state. Other states would have some incentive to keep up with regulatory changes in other states in order to avoid losing revenues.

The problem with this straightforward proposal is that representatives from states that expect to lose revenues from the proposal would be likely to oppose it. A 50-50 allocation of the tax base (i.e., the premium paid) between the state of the insured and the state of the insurer accordingly might be politically more feasible. ${ }^{49}$ The states would determine their own tax rates. Under this approach, states have an incentive to compete because they lose tax revenue if their insurers either charter elsewhere or lose market share from operating under inefficient regulation. However, even the least competitive states would not lose all tax revenues because they would share the tax revenues earned from firms chartered in the dominant states.

A potential problem with this approach is that a sudden shift to the new regime could benefit the states that are in position to gear up for competition most quickly. Firstmover advantages may stunt the development of vibrant jurisdictional competition. The problem might be mitigated by phasing in the allocation. For example, under a six-year phase-in, the split would go from 100-0, 90-10, 80-20, 70-30, 60-40, to 50-50 in the sixth year.

It is difficult to predict the type of market that would evolve. States with smaller markets might have a stronger incentive to specialize in the market for insurance regulation because their potential payoff is a larger share of total tax revenues than for smaller states. On the other hand, states where major insurance companies are headquartered may take the lead in order to capture an incumbent advantage. The jurisdictional competition under a single-license approach might lead to overall lower insurance rates as dominant states have an incentive to attract firms by reducing their chartering firms' operating costs.

\section{MARKET-BASED SOLVENCY STANDARDS}

As discussed in Part I, a key aspect of state insurance regulation is setting solvency standards that ensure that insurers can pay insured claims. Part II shows that the credibility of solvency regulation is bolstered to some extent by the "warranty" states effectively provide through their guaranty funds. These funds help ensure that states will not force rates so low that they do not cover risks. The problem here, and an impetus toward increase federalization, is the concern that state guaranty funds may not be

49 See David A. Hyman, Health Insurance: Market Failure or Government Failure? U Illinois Law \& Economics Research Paper No. LE08-003, available at http://ssrn.com/abstract=1087830 Note that while the premia would be allocated, the states determine the tax rate on these premia. 
adequate. Yet as discussed above, ${ }^{50}$ allowing optional federal chartering would effectively federalize solvency regulation through the creation of a federal guaranty fund.

One approach to solving the problems of regulating solvency without excessive federalization is to use market-based solvency measures. States could continue to regulate solvency, as they have done, ${ }^{51}$ under the law of the chartering state. States that wanted to provide more protection for local consumers could do so by requiring both local chartered and out-of-state chartered firms to have a minimum market rating. Higher-rated firms would presumably charge more for equivalent coverage. Each state's voters could decide how much risk they want to be allowed to take. Moreover, to the extent that state rate regulation increases default risk, this would be reflected in ratings. This system would permit competition and experimentation. Because it relies on the outputs of regulation - that is, the observed financial safety of companies - rather than less observable regulatory inputs, consumers have less need for a backup guaranty fund, whether provided at the state or federal level.

An alternative mechanism that would provide safety comparable to state funds without federalization would be federal regulation that requires insurers to issue solvency bonds that default if the state guaranty fund fails. The yield on these bonds would reflect the dispersed information available in the market rather than investigation by individual bond rating agencies. These information sensitive bonds would provide a market-based monitoring mechanism that would be independent of rating agencies and free from political influence. A state's temptation to regulate rates or lower solvency standards would be disciplined by the increase in the cost of the bond for firms chartered in the state. Firms would avoid states whose charters increase the cost of the bond, thereby removing states' incentives to race to the bottom by under-regulating solvency.

\section{CHOICE OF CONSUMER PROTECTION LAW}

The single-license solution ultimately provides consumer protection through nationwide rate competition, incentives and ability to offer new products, and increased information in national advertising. However, markets do not operate perfectly, and consumers may look to their home state insurance regulators for help.

The consumer protection function of state insurance regulation is the biggest problem for state-based regulation where policies are sold in interstate markets. A single license could enable out of state insurers to evade the consumer protection laws in states where insureds reside. Imposing residence-state regulations raises the specter of burden insurers with multiple regulations as under current law. On the other hand, concerns about a regulatory race-to-the-bottom, whether or not realistic, ${ }^{52}$ make a single-license model a political non-starter unless it gives states some opportunity to protect their residents. This, of course, is also a problem with OFC proposals: the fact that the single regulator is the federal government will not eliminate calls for an additional layer of state protection.

\footnotetext{
50 See supra subpart IV.B.

51 See supra text accompanying note 43.

52 See infra subpart IV.A.
} 
One possible approach to the risk of laxity would be to protect consumers and preserve state regulatory authority through a federal law that permits single-license companies to be regulated under the law of their chartering jurisdiction but only if they clearly disclose to consumers whether they comply with local state law. Consumers could then choose between "state approved" and "state unapproved" systems. This compromise is unlikely to assuage proponents of state regulation, who will argue that the whole point of state regulation is to protect consumers who may not be able fully to evaluate the risks of regulatory competition. Moreover, this system would add little to what the market could do on its own - i.e., disclosure of private industry certification, as by some NAICtype body. Indeed, the applicable state standards probably would be written by the NAIC.

A superior solution would be a federal contractual choice of law statute. Under our proposed statute, the state law designated in the insurance policy would apply to all matters concerning the application and validity of the insurance policy. The insurer could designate the consumer protection law of any state, including but not limited to the chartering (licensing) state. However, the regulation of a state in which the policies are sold could trump the designated state law if the regulating state explicitly prohibits enforcement of the choice-of-law clause. ${ }^{53}$

This proposal builds on the positive structure of jurisdictional competition and choice of law as observed in many areas of the law. ${ }^{54}$ Even in the absence of a federal push, the states have broadly enforced contractual choice of law. For example, the development of the internal affairs doctrine in corporate law proceeded spontaneously and without any special help from federal law. ${ }^{55}$ States enforce contractual choice of law even though this tends to undercut their own regulatory efforts because if they do not do so firms can take their business to other states or turn to Congress for help. The problem with this system is that it tends to work slowly and imperfectly. Our proposed federal statute will give the system a nudge in the general direction it is likely to go on its own.

The proposed statute's general default rule calling for enforcement of choice-oflaw clauses would enable companies to choose the single law that best suits their business and to have that law govern its policies wherever they do business. Because the chosen law need not be the chartering state, insurers can "unbundle" their regulatory preferences and charter in states that are good at financial regulation while choosing to have their policies governed by states that are good at consumer regulation. This addresses the problem of national firms facing 51 different regulatory regimes. The likely result is that one or a couple of jurisdictions will have the incentive to invest in developing efficient regulatory regimes - perhaps Connecticut, which already has a significant investment in regulating insurers and hedge funds.

\footnotetext{
53 For a discussion of a similar proposal for a general federal contractual choice of law statute, see O'Hara \& Ribstein, supra note 20, Ch. 11.

54 See, generally, id.

55 See Larry E. Ribstein \& Erin A. O'Hara, Corporations and the Market for Law, 2007 Ill. L.
} Rev. 661. 
The proposed approach also addresses consumer groups' concerns with a potential regulatory race to the bottom by permitting state override of contractual choice of law. At the same time, our approach includes several significant conditions designed to protect insurers from excessively burdensome multiple state regulation: (1) any state override must be by the legislature; (2) the override only applies if enacted in a state where policies are sold; (3) the override is effective only as to policies sold after the legislation is enacted; and (4) the insurer has a clear right to exit the state. ${ }^{56}$

The requirement of enactment by the legislature serves two purposes. First, it gives insurers certainty and ex ante predictability. Insurers will know before selling policies in a particular state whether their chosen law will apply, rather than having to wait for a judicial determination of the effect of the state on choice-of-law contracts under vague choice-of-law rules. ${ }^{57}$ Second, it provides an implicit political check on state incentives to override contractual choice of law. An interest group that seeks to regulate insurance policies in the state must bear the burden of getting political support not only for the regulation itself, but also for invalidating attempted avoidance of the regulation through contractual choice of law. This forces the full effect of the law to the enactment stage rather than deferring some of it to the judicial level when courts adjudicate validity of choice-of-law clauses.

The stipulations that state override applies only to policies sold in the regulating state after the passage of the regulation and ensuring insurers' right to exit maximize insurers' ability to avoid oppressive state laws. This raises the political ante for proregulatory interest groups because exit can impose costs on local consumers and others. Legislatures would have to take into account at the time of enactment lobbying not only by the insurers that would be subject to the regulation, but also by consumers and others who would be hurt if firms left the state in order to avoid the law.

In general, all of the relevant parties may be willing to accept the equilibrium that is likely to prevail under our proposed law. States may be able to live with a regime in which some can compete to become dominant regulators while others retain a limited ability to impose their own rules. Consumer groups retain the ability they currently have to lobby at the state level. And multi-state insurers would face a reduced risk of multiple state regulations that would probably approximate what they should expect to have to deal with under optional federal chartering.

\section{THE ROLE OF FEDERAL REGULATION}

The single-license proposal outlined in Part III would preserve the central state role in insurance regulation, while addressing the problem under current state law of exposing insurers to multiple regulators. The federal government's main role in our approach is as a sort of traffic cop - that is, enacting the necessary structural groundwork to ensure that states enforce the sole licensing state's law except in specific circumstances specified in the statute.

56 On the problems caused by exit restrictions, see Epstein, supra note 21, and the recent history of Mississippi, supra note 22.

57 See supra text accompanying note 19. 
This Part considers what, if any, additional role the federal government should play in enacting and enforcing substantive regulation. Subpart A discusses the main arguments for federal regulation. Subparts B and C discuss specific types of federal regulation that might respond to these concerns. We emphasize the problem of designing such regulation to deal with the potential problems of single licensing without undermining the advantages of regulatory competition.

\section{A. THE CASE FOR FEDERAL LAW}

Critics of our single-license approach are likely to raise two general types of objections. First, consumer advocates may argue that legislators and regulators would try to attract insurers, and the tax revenues they bring with them, by promising not to regulate strictly. This "race-to-the-bottom" would destabilize insurance guaranty funds and put consumers at risk. Second, insurers may fear that our proposed qualifications on single licensing would leave the door open for continued aggressive regulation by multiple state regulators. The following sections address these issues.

\section{Race to the bottom}

The appropriate starting point in addressing the race-to-the-bottom argument is whether the risk of such a race is greater for insurance regulation than for corporate law, which provides the model for state chartering. Corporate legal scholarship has generally supported the conclusion that the competition between the chartering states benefits shareholders. ${ }^{58}$ Do the same considerations apply to single-state licensing of insurers?

One might argue that the corporate internal affairs doctrine (IAD), which is the basis of state competition in corporate law, is stable precisely because it does not attempt to invade traditional areas of state regulation. ${ }^{59}$ The IAD is fairly narrow, and excludes controversial aspects of regulating corporations, such as securities fraud and disclosure, antitrust law, bankruptcy and myriad types of corporate conduct, for treatment by federal law or state law that is not within the IAD. The corporate law market relates only to substantive corporate governance. In public corporations these are standard rules which are priced fairly accurately in efficient stock markets, while in closely held firms they are subject to negotiation by engaged business people. The IAD's triviality may partly explain why Congress has not preempted the field, though it clearly has the power to do so.

Insurance regulation arguably bears a closer resemblance to traditional consumer protection law, and therefore is likely to trigger much stronger objections to applying firms' chosen state law. There are, however, reasons for skepticism about the fear of race to the bottom in insurance regulation through primary state regulation. Even in such areas as environmental regulation, there are theoretical and empirical questions about the

58 See Romano, supra note 3; Ralph K. Winter, Jr., State Law, Shareholder Protection, and the Theory of the Corporation, 6 J. LEGAL STUD. 251, 256 (1977); Peter Dodd \& Richard Leftwich, The Market for Corporate Charters: "Unhealthy Competition” Versus Federal Regulation, 53 J. BUS. 259 (1980).

59 Ribstein \& O'Hara, infra note 55. 
validity of the race to the bottom story. ${ }^{60}$ With respect to insurance regulation, as already noted, ${ }^{61}$ even unsophisticated consumers are protected by robust markets.

Moreover, state regulation in the absence of choice of law has not necessarily protected consumers. For example, it took Eliot Spitzer to react to existing problems of broker contingent compensation. Some would say that Spitzer overreacted, but the fact would remain that there was a problem that dispersed state regulators had not addressed. ${ }^{62}$ By contrast, recognizing a clear default rule of enforcement of choice of licensing jurisdiction is likely to induce some states to invest in developing a reputation for prudent insurance regulation. This may result in greater consumer protection than under the current regime of dispersed regulators, thereby reducing states' incentives to override contractual choice. For example, Vermont has maintained a dominant role as the jurisdiction of choice for captive insurers, not through laxity, but in part by maintaining a reputation for stringent financial integrity regulation that has kept the liquidation rate of Vermont associations lower than that of other states. ${ }^{63}$

Thus, single-state licensing not only promises to reduce regulatory costs, but also to produce more efficient and effective regulation. But despite these arguments against the "race-to-the-bottom" objection, we have attempted to mitigate this risk through federal market-based constraints on solvency regulation ${ }^{64}$ and by allowing for limited state override of the licensing state to protect consumers. ${ }^{65}$ Particularly with these safeguards in place, extensive federal regulation of insurance is unnecessary. The modest proposals in subparts $\mathrm{B}$ and $\mathrm{C}$ are intended to fill any remaining gap in protection without opening the door too wide for federal regulation to supplant state competition.

\section{Excessive state regulation}

Insurers may object that the limitations we propose on state competition raise the problem that aggressive state legislatures may take advantage of their power to override the single license and impose multiple regulatory burdens on insurers. However, it is important to keep in mind that would-be regulators are subject to the significant risk that insurers will respond by lobbying Congress for a federal insurance law that would preempt state regulation. State regulation, particularly of a national industry like insurance, always exists in the shadow of potential federal law. To minimize the risk of being supplanted by federal law, states may either refrain from regulating except to fight

60 See Richard L. Revesz, Rehabilitating Interstate Competition: Rethinking the "Race-to-theBottom” Rationale for Federal Environmental Regulation, 67 N.Y.U.L. Rev. 1210 (1992); Henry N. Butler and Jonathan R. Macey, USING FEDERALISM TO IMPROVE ENVIRONMENTAL POLICY (AEI Press, 1996); ENVIRONMENTAL FEDERALISM (Terry L. Anderson and P.J. Hill, eds. 1997); Jonathan H. Adler, Judicial Federalism and the Future of Federal Environmental Regulation, 90 IOWA L. REV. 377 (2005).

61 See supra text accompanying note 10.

62 See Warfel, supra note 44; Scott, supra note 6 (discussing problems with dispersed rate regulation).

63 See Warfel, supra note 44.

64 See supra subpart III.C.

65 See supra subpart III.D. 
the clearest abuses, or opt for uniform state laws through the NAIC that at least reduce the risk of duplicative and opportunistic regulation.

Given the persisting risk of federal regulation, our single-license approach could be viewed as a kind of trial run for state law. The states have been the exclusive insurance regulators for sixty years. The problems of state regulation have led to loud calls for federal regulation from both consumers and insurers. We argue in this paper for rehabilitation of state regulation by opening this regulation to jurisdictional competition. But if this rehabilitation does not work, state regulators understand that the calls for federal regulation may become politically irresistible.

Insurers may respond that the political costs and risks of dismantling the state competition regime diminish any disciplinary effect of potential federal regulation. This suggests that it may be appropriate to establish a federal regulatory structure that would be ready to step in if needed without having to do a full-fledged overhaul of the existing regime. The proposals in subparts $\mathrm{B}$ and $\mathrm{C}$, below, might serve this function in addition to addressing potential for a race-to-the-bottom.

\section{B. OFFICE OF NATIONAL INSURANCE}

Secretary Paulson's Treasury Plan calls for the creation of a specialized federal office to monitor insurance markets. ${ }^{66}$ The proposed Office of National Insurance could play an important role in our single-license scheme of collecting, disseminating, and analyzing information about the effectiveness of state jurisdictional competition. The data would indicate if state regulation has been too lax or if states are imposing excessive regulatory burdens on insurers.

In order to increase the disciplinary effect of the federal insurance office, the office could be empowered to impose specified types of regulation and preempt state law if it makes the requisite findings. This would move the federal preemption threat from the background to a foreground concern for lax or aggressive state regulators. This is comparable to the Securities and Exchange Commission's power to supplement or preempt state corporate law under its general authority to regulate national securities markets.

The obvious problem with establishing this federal mechanism is the pervasive concern that such an agency will succumb to the well-known bureaucratic tendencies to expand its mission and authority. In order to deal with this problem, the agency's power needs to be carefully circumscribed and the conditions of its intervention need to be described as precisely as possible.

The national insurance office would have the additional function and benefit of better enabling U.S. insurers to enter foreign markets. Critics of state law have suggested that U.S. insurers are at a competitive disadvantage in attempting to enter foreign markets because it is hard for dispersed state regulators to offer reciprocal privileges to foreign insurers entering the U.S. This problem would be alleviated under our approach because the foreign insurer would only have to obtain a single license. However, the problem would continue to some extent because no one regulator would represent U.S. interests in

66 See Treasury Blueprint, supra note 7, at 128. 
international negotiations. The proposed national insurance office could not only be a way to clarify the state licensing alternatives available to foreign entrants, but a mechanism for negotiating international treaties.

\section{TRULY OPTIONAL FEDERAL CHARTERING}

Lax or aggressive state regulators might be disciplined not only by the threat of federal regulation, but also by offering insurers the additional choice of a federal charter. As discussed in subpart II.B., the current proposal for optional federal chartering does not offer a true option for several reasons: insurers' only other choice is continued exposure to regulation in each state in which they sell insurance; the federal government is likely to be able to back up its regulation with a better solvency guaranty fund than any state regulator; and the federal government would be able to quickly offer higher quality regulation than what any state has developed under the weak incentives of the current state regulatory system. The single-license proposal would give states a competitive incentive to offer superior regulation, thereby arguably making optional federal chartering unnecessary.

Although optional federal chartering may be unnecessary under a favorable view of state competition, it offers a potential alternative for insurers or consumer groups that object to our single-license alternative. It is important to emphasize that we are referring to truly optional chartering, in which the federal charter competes on a level playing field with state chartering.

Leveling the playing field would involve not only offering the possibility of a single state license, but also giving the states the opportunity to develop viable regulation under competition before the federal government can enter the competition. Making the federal option available immediately may stifle the development of jurisdictional competition by the states. Accordingly, we suggest making the federal charter available after a reasonable transition period of five years or so. An alternative would be to empower the national insurance office proposed above to recommend the desirability or need for a federal charter option after five years experience under our single-license approach.

Truly optional federal chartering could be designed to address both of the problems with single licensing identified in subpart A. Federal chartering might deal with the problem of multiple state regulators overriding chartering state law by providing that the federal charter preempts state consumer protection regulation. Preemption is arguably justified on the basis that the federal government has less revenue incentive than a small state to race-to-the-bottom to attract chartering business.

Federal chartering also could address state laxity by providing a superior guaranty fund as a "warranty" to back solvency and rate regulation. This would not only protect consumers, but also could attract chartering business from insurers. Insurers could decide whether they want the most efficient state regulation that has developed under singlelicense competition, backed by the market-based solvency protection, ${ }^{67}$ or to offer their customers the security of a federal guaranty, presumably at a higher price.

${ }^{67}$ See supra subpart III.C. 
It is important, however, to keep in mind the caveat that the federal option always has the potential to overwhelm even efficient state competitors, resulting in a noncompetitive system with a single federal regulator. ${ }^{68}$ Because of this danger, federal chartering should be made available only if there is a preliminary finding by Congress or the national insurance office that there are defects in the competitive single-license state system.

\section{CONCLUSION}

All proposals to federalize insurance regulation - whether through mandatory or optional federal laws - create opportunities for abuse at the hands of the federal government. Monopoly national regulation of the insurance industry should be viewed with skepticism by both industry and consumers. Insurance carriers could be subject to rent extraction by the federal regulator, while consumers should be concerned about industry capture of the centralized regulatory agency. This article proposes a state-based regime that both protects insurers from the worst effects of multiple regulators and creates a real opportunity for jurisdictional competition and experimentation. To be sure, a state-based regime is not perfect. But a single federal regime also has serious potential drawbacks, particularly including the absence of a mechanism to correct its errors. We have proposed a set of checks and balances to help protect against the potential malfunctioning of the state system. There is no guarantee that state competition is a panacea. But given the strong potential benefits of state competition under our singlelicense approach, it is certainly worth trying before scrapping state law in favor of a single federal regulator.

68 For a discussion of the Canadian experience with an optional federal corporation law, see Ronald J. Daniels, Should Provinces Compete? The Case for a Competitive Corporate Law Market, 36 MCGILL L.J. 130 (1991) (noting dysfunctions that can arise in competition between federal and state chartering jurisdictions). 